\title{
M MONTANA
}

Yearly food habits of the river otter in the Thompson Lakes region, northwestern Montana, as indicated by scat analyses

by Kenneth R Greer

A THESIS Submitted to the Graduate Faculty in partial fulfillment of the requirements for the degree of Master of Science in Fish and Wildlife Management

Montana State University

(C) Copyright by Kenneth R Greer (1953)

Abstract:

A food habits study by scat analysis was conducted from April, 1952, through May, 1953, in the Thompson lakes region of Lincoln County, Montana to help evaluate the economic status of the river otter (Lutra canadensis) Ninety-six otter latrines supplied 1374 scats with a known date of deposit. Material was gathered from two separate areas and analyzed data were compared. Limited sampling was conducted to obtain a suggestion of fish abundance and "sign" was used to estimate fur bearer numbers to help evaluate the food habits. For the entire year and for both areas fish remains were identified most frequently, appearing in 1280 (93.2\%) of the 1374 scats. Invertebrates were recorded for $566(41.2 \%)$, amphibians 233 (18.4\%), mammals 212 (15.4\%), birds $71(5.2 \%)$ and reptiles 5 $(0.4 \%)$. Each of these groups retained the same position in relative importance throughout all seasons except fall when mammals replaced amphibians for third.

The data suggest availability of prey to be important in determining the food habits' of the otter. 


\section{MONTANA STATE UNDVERSETV

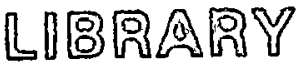

YEARIY FOOD HABITS OF THE. RIVER 'OTTER IN THE THOMPSON' LAKES REGION, NORTHWESTERN MONTANA, AS INDICATED BY SCAT ANALYSES.

'by

KENNETH R. GREER

A THESIS

Submitted to the Graduate Faculty

in

partial fulfillment of the requirements

for the degree of

Master of Science in Fish and Wild]ife Management

at

Montana State College

Approved:

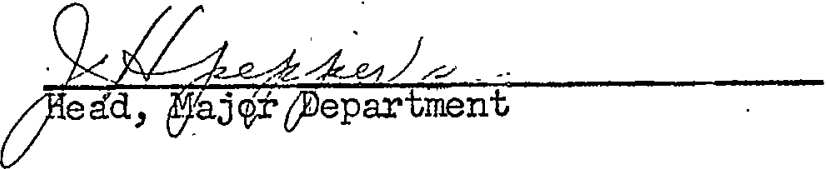
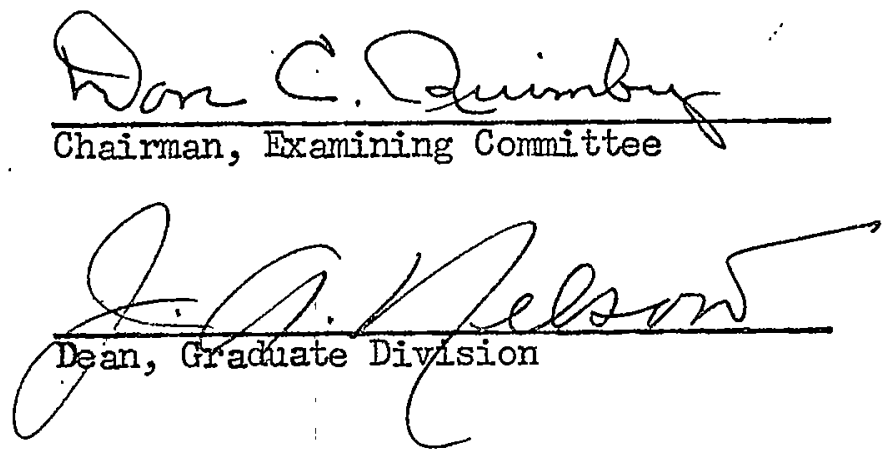

Bozeman, Montana

August, 1953 


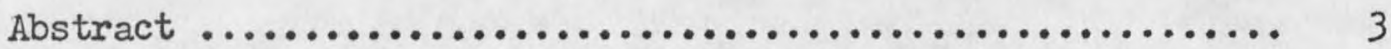

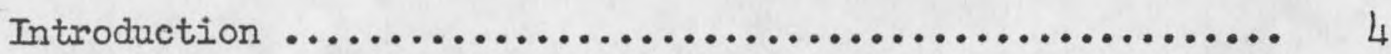

The study area $\ldots \ldots \ldots \ldots \ldots \ldots \ldots \ldots \ldots \ldots \ldots \ldots \ldots \ldots \ldots \ldots \ldots \ldots$

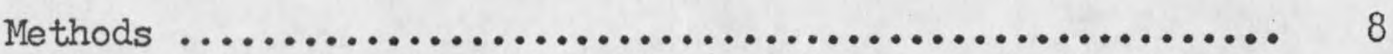

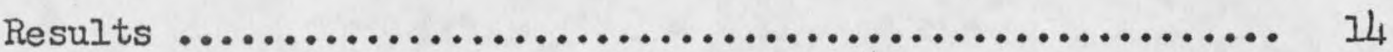

Comparison of Thompson and Gary areas ............. 18

Tapeworm incidence ............................ 23

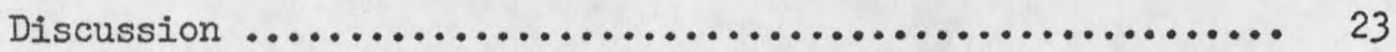

Conclusions and recommendations .................... 26

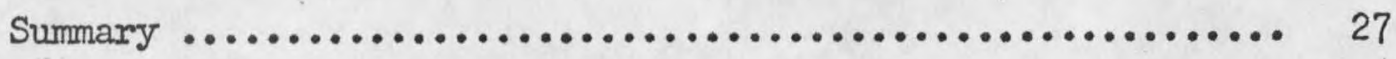

Literature cited $\ldots \ldots \ldots \ldots \ldots \ldots \ldots \ldots \ldots \ldots \ldots \ldots \ldots \ldots \ldots . \ldots \ldots$ 


\section{ABSIRACT}

A food habits study by scat analysis was conducted from April, 1952, through May, 1953, in the Thompson lakes region of Lincoln County, Montana, to help evaluate the economic status of the river otter (Iutra canadensis). Ninety-six otter Iatrines supplied 1374 scats with a known date of deposit. Material was gathered from two separate areas and analyzed data were compared. Iimited sampling was conducted to obtain a suggestion of fish abundance and "sign" was used to estinate fur bearer numbers to help evaluate the food habits. For the entire year and for both areas fish remains were identified most frequently, appearing in 1280 (93.2\%) of the 1374 scats. Invertebrates were recorded for 566 ( $41.2 \%)$, amphibians 253 $(18.4 \%)$, mammals 212 (15.4\%), birds 71 (5.2\%) and reptiles 5 (0.4\%). Each of these groups retained the same position in relative inportance throughout all seasons except fall when mammals replaced amphibians for third. The data suggest availability of prey to be important in determining the food habits of the otter. 


\section{INTRODUCTION}

Otters (Iutra canadensis) have been protected in Montana since the 1949-50 trapping season but there is evidence that a few are unintentionally taken in traps and there are rumors that some are eliminated by acts of vandalism. Certain unfounded reports from Lincoln County indicated these animals are undesirable. Some fishermen claim they reduce the numbers of trout and bass and thus contribute to poor fishing. Some trappers declare otters destroy miskrats, beavers and minks. A survey of the literature did not reveal information to substantiate or refute these claims so it seemed desirable to conduct a study.

The writer wishes to thank the Montana Fish and Game Department for financial support and also Fletcher $\mathrm{E}$. Newby of this department for his interest and cooperation during the project. Sincere appreciation is extended to Drs. Don C. Quimby for encouragement and guidance during the 'study and critical review of the manuscript.

\section{THE STUDY AREA}

The investigation was centered around Thompson Lakes, a group of 31 lakes and streams, situated approximately 40 miles southeast of libby, Montana (Fig. 1). These lakes are easily accessible and many can be seen from U. S. Highway No. 2.

Fishes native to the area include: Kokanee salmon (Onchorhynchus. nerka), dolly varden trout (Salvelinus malma), cutthroat trout (SaImo clarkii), rocky mountain whitefish (Prosopium williamsoni), Columbia coarse scaled sucker (Catostomus macrocheilus), Columbia long-nosed 


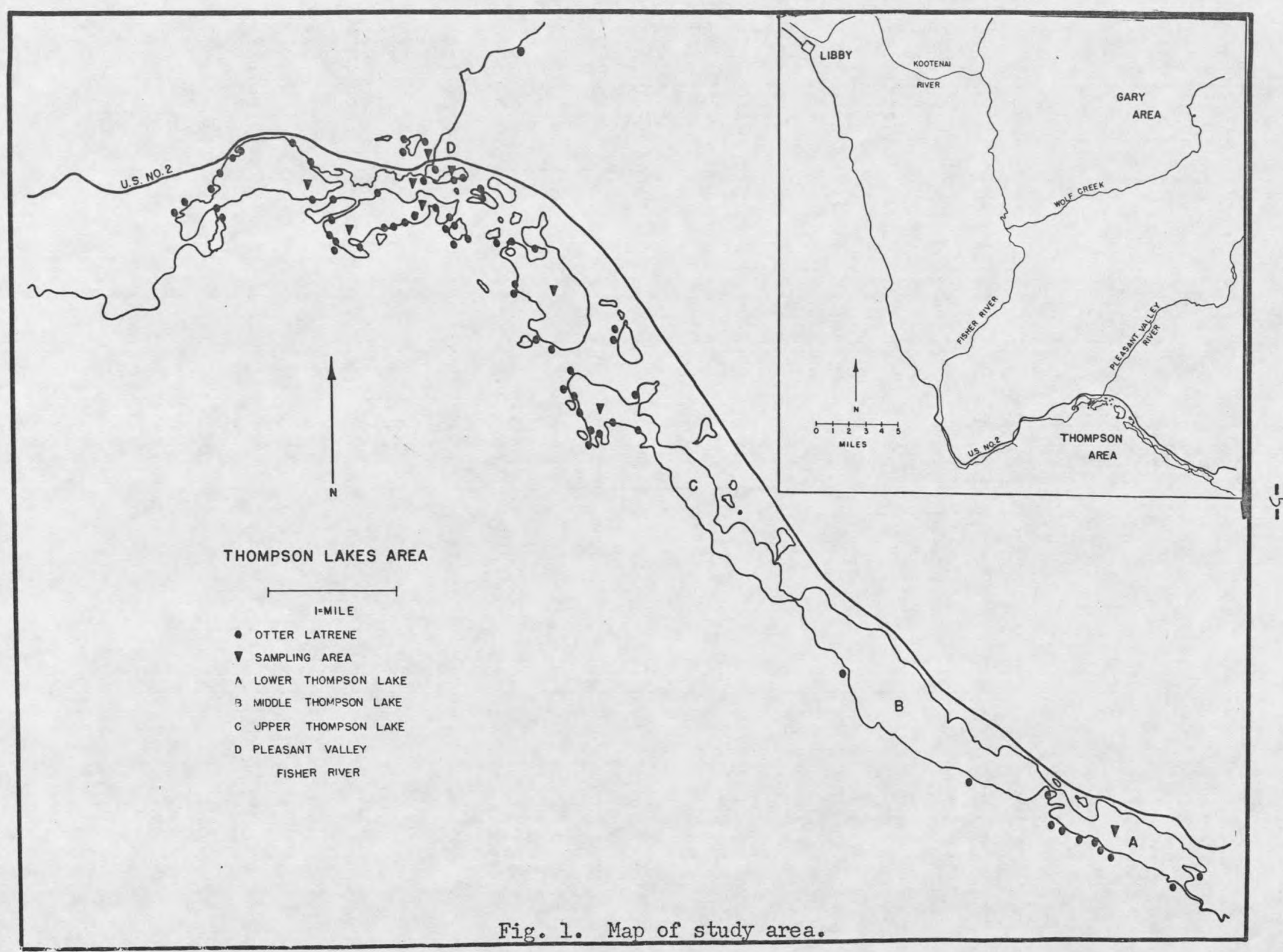


sucker (Catostomus catostomus), red-sided shiner (Richardsonius balteatus), sculpin (Cottus punctulatus), squawfish (Ptychocheilus oregonensis) and Columbia river chub (Mylocheilus caurinus). Hybrids between the latter two were common. Exotics include: Eastern brook trout (Salvelinus fontinalis) rainbow trout (SaImo gairdnerii), largemouth bass (Micropterus salmoides), yellow perch (Perca flavescens) and pumpkinseed (Eupomotis gibbosus). According to Echo (personal communication) there exists an over population of perch and sunfish.

Gill nets, electric shacking equipment and fishing were employed to obtain information on fish abundance in the various waters ( $T a b I e ~ I)$. An Indication of muskrat (Ondatra), mink (Mustela), and beaver (Castor) numbers was afforded by "sign" (Table II).

Gary's Lake, about 20 miles due north of the Thompson Lake area was included for comparison because it is somewhat isolated and supports a greater concentration of fur bearers.

Only on three occasions were pairs of otter observed within the study areas. Few sight records were reported. Liers (195I), observed dens of three litters along a 20 mile stretch of stream in Minnesota. No dens were seen in this study. Two otter were observed on a small lake ( 8 acres) for 2 hours. They were not observed to eat anything. During the 5-10 minutes they were on the shore they deposited 3 droppings. This one direct observation was not sufficient to determine the number of scats deposited by an otter in a given length of time. The number of scats collected at latrines between known dates, and known or estimated dates 
Table $\mathbb{F}_{0}$ Relative abundance of fish in study area as indicated by limited sampling.

\begin{tabular}{|c|c|c|}
\hline Area and Date & Sampling Me thod & Catch \\
\hline \multicolumn{3}{|l|}{ Thompson } \\
\hline $\begin{array}{l}\text { (9 sampling areas, } \\
\text { see fig。 } 1 \text { ) } \\
\text { June-Aug. }\end{array}$ & $\begin{array}{l}7 \mathrm{hr} \cdot \text { fishing } \\
(4 \text { areas })\end{array}$ & $\begin{array}{l}50 \mathrm{YP} \text { in } 2 \mathrm{hrs} ., 100 \mathrm{SF} \text { in } 3 \\
\text { hrs. } 10 \mathrm{SU} \text { in I } \mathrm{hr} ., 12 \mathrm{cRC} \text {, } \\
8 \mathrm{SF} \text { in } 1 \mathrm{hr} .\end{array}$ \\
\hline Sept. 3 & $\begin{array}{l}\text { electric shocking } \\
\text { ( } 2-100 \text { ft. stream } \\
\text { sections) }\end{array}$ & $\begin{array}{l}76 \mathrm{SC}, 2 \mathrm{SU}, 16 \mathrm{~T}, 10 \mathrm{~S}, \\
7 \mathrm{WH}, 3 \mathrm{SH}\end{array}$ \\
\hline June-Sept。 & $\begin{array}{l}* 70-24 \text { hr. gill } \\
\text { net sets ( } 1 \text { area) }\end{array}$ & $\begin{array}{l}\text { (avo catch per } 24 \mathrm{hr} \text {. set) } \\
63 \mathrm{IP}, 35 \mathrm{Wr}, 17 \mathrm{~S}, 7 \mathrm{SF}, \mathrm{ISU}\end{array}$ \\
\hline $\begin{array}{l}\text { May, Aug. } \\
\end{array}$ & $\begin{array}{l}13-24 \text { hro sets } \\
(3 \text { areas })\end{array}$ & $\begin{array}{l}28 \mathrm{SF}, 22 \mathrm{~S}, \mathrm{I} 4 \mathrm{CRC}, 6 \mathrm{~B}, 3 \mathrm{~T}, \\
2 \mathrm{WF}, 1 \mathrm{SU}\end{array}$ \\
\hline $\begin{array}{l}\text { Gary's } \\
\text { (1.area) }\end{array}$ & 2 hrs. fishing & $4 \mathrm{SH}_{2}, 2 \mathrm{~T}$ \\
\hline
\end{tabular}

B-bass, CRC-Columbia river chub, S-sucker, SC-sculpin; SF-squawfish, SH-shiner; SU-sunfish, T-trout, WF-whitefish; YP-yellow perch:

*The data of 70 gill net sets were supplied by John Echo while working on a fish study in the lower Thompson Lake.

Table II. Relative abundance of fur bearers in study area as indicated by "sign".

\begin{tabular}{|c|c|c|c|c|}
\hline Area & $\begin{array}{l}\text { Av. no. } \\
\text { beaver } \\
\text { houses }\end{array}$ & $\begin{array}{c}\text { Av. } \\
\text { beaver } \\
\text { "sign" }\end{array}$ & $\begin{array}{l}\text { Av. } \\
\text { muskrat } \\
\text { "sign" }\end{array}$ & $\begin{array}{c}\text { Av. } \\
\text { mink } \\
\text { "Sign" }\end{array}$ \\
\hline $\begin{array}{l}\text { Thompson } \\
-(9 \text { sampling areas })\end{array}$ & 1.3 & $X$ & $X X$ & $X$ \\
\hline $\begin{array}{l}\text { Gary's } \\
\text { (1.area) }\end{array}$ & 3.0 & $x x x$ & $x x x$ & $x$ \\
\hline
\end{tabular}

X-Iight, XX-Moderate, XXX-Heavy 
of scat deposition, revealed few otter in the area. Those present usually remained only a day or two in any one locality. According to liers (op cit), "Individuals may cover 50 to 60 miles of stream course in a year. Families range about 3 to 10 miles in a current season". The extensive home range of the otter in the study area is indicated by the dates scats were deposited at known latrines. During spring, the deposits seemed to show a visit to an area for a day or two, absent 2 or 3 days, returm for a day and absent 2 or 3 days. This pattern was repeated 3 or 4 times then an absence between visits of 7 to 15 days occurred. The frequency of visits decreased as summer progressed. Scat evidence suggested that otters deserted the lakes when they became frozen over. The fact that. droppings were deposited on the same day at Gary's and the Thompson area, separated by 28 water miles, indicated each of these areas served as separate home ranges for the otter inhabitants. The number of otters estimated to use the study area was $6-8$.

\section{METHODS}

"Pulling out" places and latrines (Liers, op cit) were located by walking the shores. Most latrines were on the shores, several were on or near beaver houses. Fallen trees, larger than 18 inches in diarneter, extending from the shore into the water were often used. Latrines appeared to be of long establishment.

Otter scats are readily recognized with experience. The average is approximately 3/4 inches in diameter and characteristicaliy in 2, 3, or 4 curved segments each about $1 \frac{1}{2}-3$ inches long making a total length of 4-7 
inches. It is not unusual for droppings to vary in size from above average to a remnant. Fresh droppings were usually' black with a strong characteristic odor. They usually consisted of fish scales and bones although other materials such as hair, feathers etc. were frequently present. Heavy micus was mixed throughout a fresh scat. Drying, crusting and decrease in mucus content progressed with age. To determine the rate of change, fresh scats were tagged, Ieft unmolested and revisited daily. Droppings from immature otter could be mistaken for those from a large mink if it were not for the smaller diameter of the latter and the characteristic one segment (Fig. 2).

An occasional "sign" noticed at a latrine site was a wite discharged substance. Some trappers reported this to be "phlegm" from an oral discharge. It was usually found separate from the scats but in their vicinity. It had an irregular form ( $1 / 8$ to $1 / 4$ inch thick and 1 to 2 inches Iong), white opaque color, elastic quality and apparently was lacking in odor. A yellow tinge accompanied aging. One trapper was reported to have used this material to make scent for trapping otter.

When a latrine was discovered all scats were aged and placed in separate envelopes on which essential data were recorded. Once the location of a Iatrine was established it was visited regularly for scat collections. Eight were Iocated at Gary's Lake and 88 on the Thompson study area. Snow made accessibility to the areas difficult throughout the winter and fall but 6 collections were made. Final collections were made after all snow disappeared and "Iost" droppings were recovered. A total of 2209 scats was collected from April, 1952, through May, 1953. The approximate date of 


\section{$-10-$}

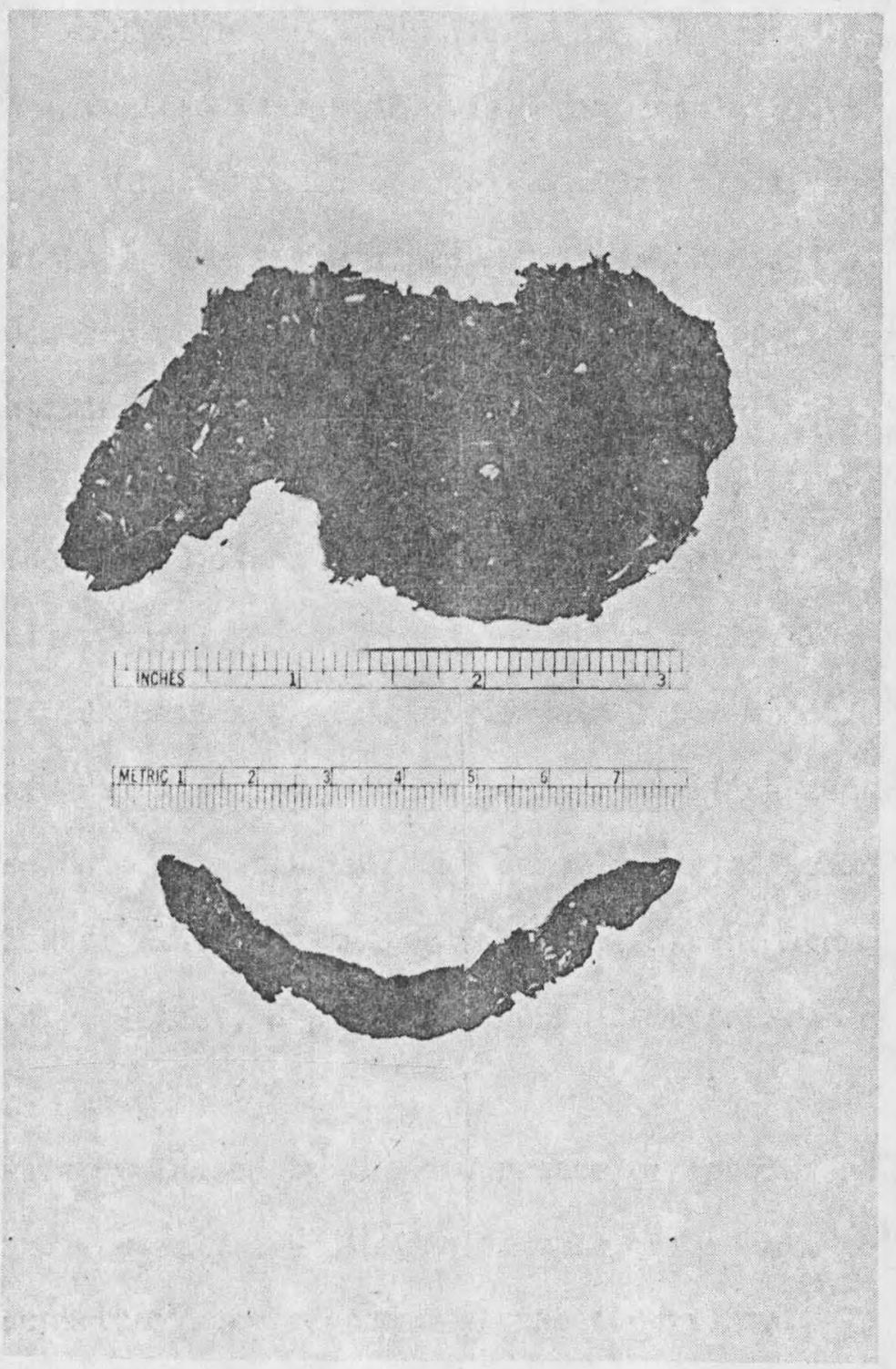

Fig. 2. Otter scat above, mink below. 
deposition was determined for 1374 which constitute the basis of this study.

Analysis of droppings was accomplished in the dry state. Scats were broken apart in a culture dish with dissecting needle and tweezer and examined under a 20x binocular microscope. Smaller items, such as hairs and parts of feathers, were reexamined under the compound microscope. The complete scat was searched for recognizable remains of items in the diet. These were identified by comparison with reference collections of bones, hair, feathers, and other undigestible materials of vertebrates and invertebrates. Identified items were recorded on the collecting envelope, placed in a smaller envelope and returned to the collecting envelope along with unidentifiable remains. All records were later transferred to a 5 by 8 inch punch card which proved invaluable in cumulating and sorting data (Fig. 3). These data were tabulated in monthly periods then grouped into seasons as follows: Winter-January, February, March; Spring-April, May, June; Summer- July, August, September; and Fall- October, November, December.

The data were evaluated by the occurrence of species only (Scott 194I, Crabb 1941, Ferrel, et al, 1953). For example, if remains of six sunfish appeared in a scat they were recorded as one occurrence. The percent occurrence was calculated by dividing the number of scats of a period into the number of occurrences of species for the same period.

Reference collections were prepared as follows: Preliminary scat examinations revealed many identifiable objects, especially bones and 


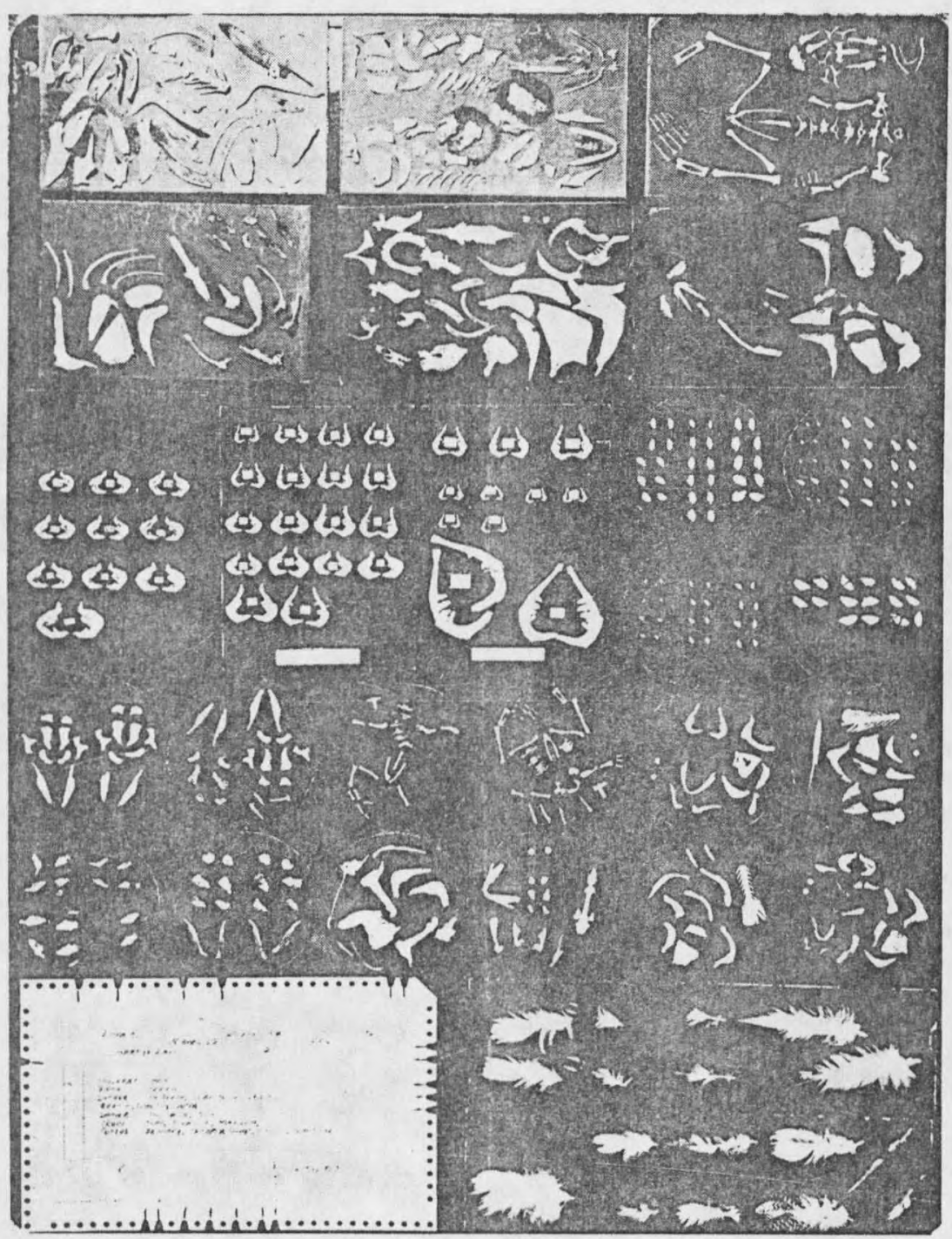

Various Skeletal Elements

Top row: Bass Trout Frog

2nd. row: Bass Sucker Whitefish

Pharyngeal Teeth

3rd. row: Columbia River Chub, Squawfish, Squawfish Perch, Whitefish

4th. Pharyngeal Teeth Bass $\frac{\text { Various Skeletal Elements }}{\text { Bow }}$ Bas, Frog, Squawfish, Columbia River Chub 5th. row: Sunfish Perch Perch, Perch, Squawfish, Columbia River Chub Bottom row: Punch card, Feather cards

Fig. 3. Representation of reference collections used to identify diagnostic items found in scats. 
scales of fishes. Other objects included bones of various vertebrates, hair, feathers, teeth, claws and exoskeletal parts of invertebrates. Vertebrates and invertebrates found in and around otter habitat were collected. Fresh specimens of fishes, frogs (Rana pretiosa), toads (Bufo boreas), snakes (Thamnophis elegans), salamanders (Ambystoma macrodactylum), and Iizards (Gerrhonotus coemuleus), were reduced to skeletal remains by boiling in water 3-5 minutes. Characteristic bones of each species such as scales, pharyngeal teeth, otoliths, maxillary, opercular, preopercular, dentary, vertebra and others were separated and mounted on colored cards (Fig. 3). A few mammals were likewise prepared but the availability of the collection at Montana state College made it unnecessary to prepare complete collections:

Reference hair collections were restricted to fur bearers (otter, beaver, miskrat, minic). Only these animals were considered in the study. Reference slides were made of the fur and guard hairs from the neck, chest, back, mump, abdomen, side and tail. Scalation, medulla structure and measurements were used as a basis for comparison with unknowns found in the scats (Mathiak 1938, Mayer 1952).

A few breast feathers from representatives of the bird orders found in and around the waters were mounted on cards. Feathers in scats were compared but only those of the Anatidae and grebes were identified. Shaft forms (round, flat, oval), barbe concentration at the base with point of departure from shaft and barbule bases were characters used for segregations. All scats and reference collections used in the study are at Montana State College. 


\section{RESULTS}

The results of the scat analysis are expressed in Table III by recording the number and percent of the scats in which an item (species) was represented. A scat usualiy contained more than one of the items reported in the table and therefore none of the percentages total 100\%.

For the entire year and for both areas fish remains were identified most frequentiy, appearing in $1280(93.2 \%)$ of the 1374 scats. Invertebrates were recorded for 566 (41.2\%), amphibians 253 (18.4\%), mammals 212 ( $15.4 \%)$, birds $71(5.2 \%)$ and reptiles $5(0.4 \%)$. Each of these groups retained the same position in relative importance throughout all seasons except fall when mammals replaced amphibians in third place. Lagler and Ostenson's (1942) sumery of early spring food of otters in Michigan, 1940 and 1941, showed stomach (in percent of total rolume of food) and intestinal analysis (in average estimated percent of food by bulk) to be: Game and pan fishes $(32.0 \%$ and $15.9 \%)$, forage fishes (17.6, 22.7), fish remains $(3.0,13.8)$, frogs and mupuppies $(16.1,7.5)$, other vertebrates (25.8, $0.9)$, insects $(0.8,4.2)$, and crayfish $(4.7,35.0)$ respectively.

Of the fish, sunfish occurred most frequently, $58.2 \%$ of all scats. It was most frequent in summer scats; $72.8 \%$ of the 604 assigned to that season. It was the most commonly represented fish during all seasons except winter when it was surpassed by the sucker. Suckers ranked second (33.3\%). They were most prominent in winter $(59.6 \%)$ and fall $(45.3 \%)$ The fish third in importance was the sculpin which occurred in 21\% of all scats and was uniformly represented throughout the four seasons. AII of 
$-15-$

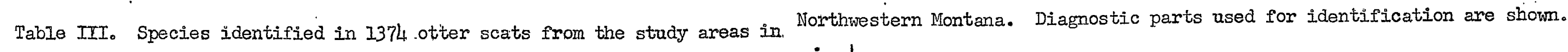

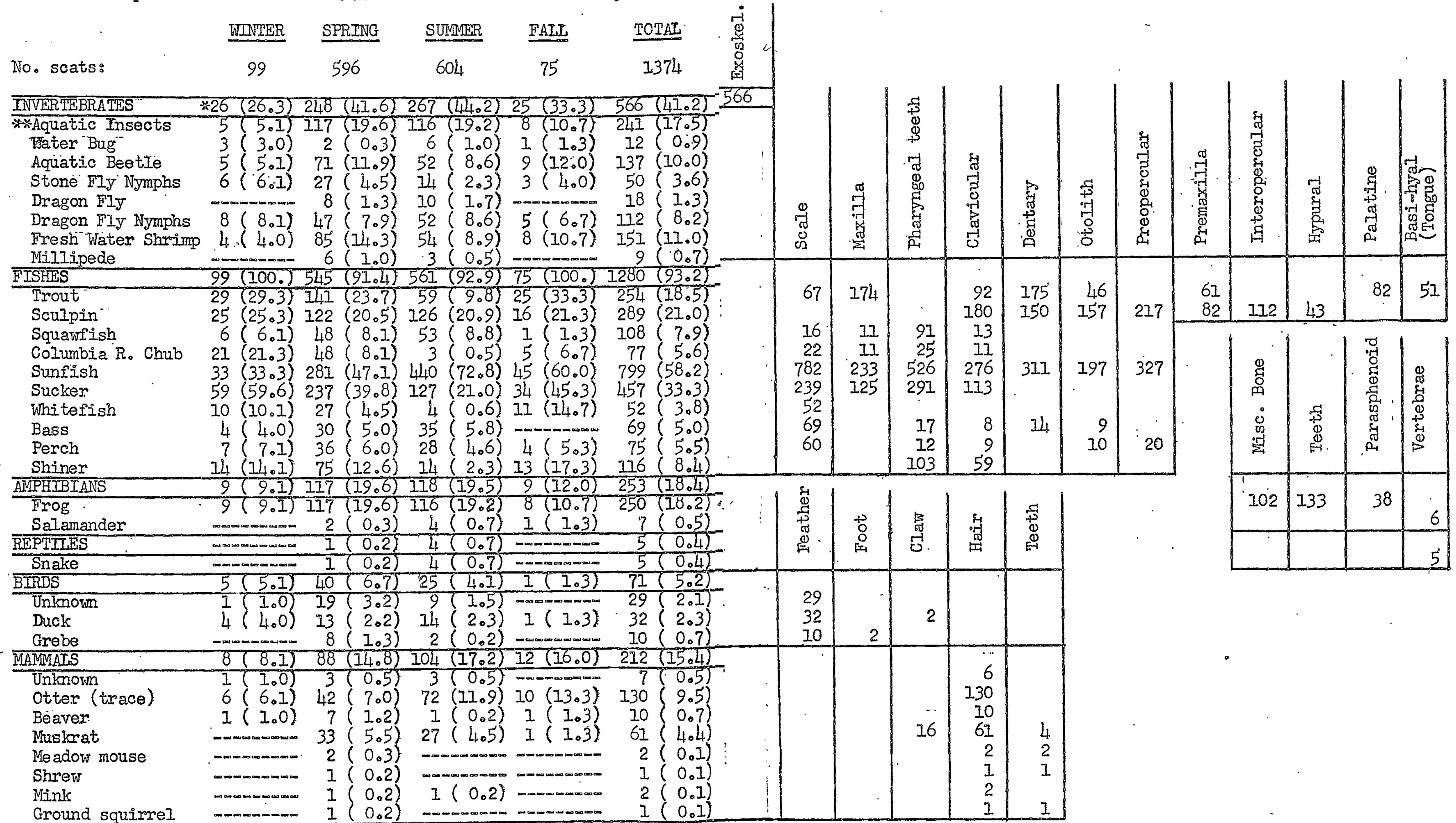

Ground squirre

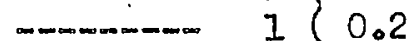

igure

* Undetermined exoskeletal fragments of aquatic insects. 
the above fishes occurred in $20 \%$ or more of the scats for each of the seasons. Trout were fourth in occurrence (18.5\%) but showed low representation in sumer (9.8\%) and high in fall (33.3\%). Other fish represented occurred in less than $10 \%$ of the droppings. In order of occurrence, they were: shiner, squawfish, Columbia river chub, perch, bass and whitefish (see Table III).

Many scats contained small insect remains that could have been in the aIimentary canals of fish taken by otter. Lagler and Ostenson (1942) concluded this in their study of otter stomachs and intestinal tracts. The larger insects represented in the scats were considered as a food taken directly by the otter.

Invertebrates considered as food were in 566 or $41.2 \%$ of the 1374 scats. The category "aquatic insects" (17.5\%) appeared to be mostly fragments of dragon fly nymphs (Odonata) (Table IIE). If this assumption is correct, then dragon fly nymphs ( $8.2 \%$ plus "aquatic insects" 17.5\%) occurred most frequently in the group followed by fresh water shrimp (Gammarus) (11.0\%) and aquatic beetles (Coleoptera) (10.0\%). The greatest occurrence of invertebrates appeared in spring (41.6\%) and summer (44.2\%). The representation for the winter and fall was 26.3 and $33.3 \%$ respectively。

Frog remains appeared in 250 or $18.2 \%$ of the droppings. The spring and summer representation was 19.6 and $19.2 \%$ respectively. They were in 9.1 and $10.7 \%$ of winter and fall scats. Salamanders were represented by a trace in all periods except winter. Mammal remains or traces of hair were found in 212 or $15.4 \%$ of the 


$$
-17-
$$

total. Periodic differences showed the winter to be lowest ( $8.1 \%$ ) with the other seasons ranging from 14.8 to $17.2 \%$ One hurdred and thirty (9.5\%) droppings contained a trace of otter hair. A trace was considered as such if it were possible to make 3 or more examination slides from the material. Otter hair was never found in greater quantity than an $1 / 8$ inch tuft suggesting it was taken while the otter was grooming itself. Fisher (1940) and Murie (1940) have observed the sea otter (Enhydra Iutris) spending much time cleaning itself and its young.

Muskrat was identified in 61 (4.4\%) of the scats. The occurrence was concentrated in spring $33(5.5 \%)$ and summer $27(4.5 \%)$, absent in winter and in one scat for the fall period. Beaver was in $10(0.7 \%)$ with greatest occurrence $7(1,2 \%)$ in the spring and showing in one scat for each of the other three seasons. Mink, meadow mouse (Microtus), shrew (Sorex), and ground squirrel (Citellus) were also identified.

of the $71(5.2 \%)^{\circ}$ scats containing feathers, 29 were undetermined, 32 (2.3\%) had duck and $10(0.7 \%)$ contained grebe feathers. Feathers appeared in $40(6.7 \%)$ scats from the spring collection, 25 (4.1\%) from the summer, $5(5.1 \%)$ in winter and $1(1.3 \%)$ in fall.

The Michigan study of Lagler and Ostenson (1942) revealed a Iimited occurrence of one mammal and two birds to be of too few data to suggest these to be staples in the food of the otter. This study, revealing occurrence of $7 I$ scats containing feathers and 212 with mamals, indicated that the otter fed upon these animals commonly.

Snakes occurred in $5(0.4 \%)$ of the total. Four $(0.7 \%)$ of these were summer scats. 
By comparing the remains of characteristic bones (Table I) in scats with reference collections it was possible to determine the approximate size of the fish eaten. Remains indicated 14 inch trout and 16 inch suckers were frequently taken. Eagler and Ostenson (op cit) report trout in the diet of otters to average $4 \frac{7}{2}$ inches, suckers 5 inches.

No "leavings" or "caches" of fishes were found to have been left by the otter. All catches seem to be completely utilized.

Western painted turtIes (Chrysemys picta) were abundant in the area but none appeared in any scat. An otter was observed sniffing a turtie which was on a $\log$ in the water without disturbing it.

On one occasion a golden eye duck (Bucephala) wing tip and a few feathers were found with ot ter "sign" close by。 During December, a mutilated frog was found on the ice next to a beaver house which showed recent otter activity, tracks and "sign"。

\section{Comparison of Thompson and Gary Areas}

The droppings from the Thompson area contained the same categories of animals and in the same order of frequency as the complete scat collection (Tables III and IV). Those found in 1122 droppings were: Fish 1093 $(97.4 \%)$, invertabrates $376(33.5 \%)$, amphibians $137(12.2 \%)$, mammals 116 $(10.3 \%)$, birds $43(3.8 \%)$ and reptiles $4(0.4 \%)$. For Garyis lake, invertebrates $190(75.4 \%)$, berely take the number one occurrence from the fishes, 187 (74.02\%). The same relations continue for the other groups: Amphibians $116(46.0 \%)$, mammals $96(38.1 \%)$, birds 28 (11.1\%) and reptiles $1(0.4 \%)$ for 252 scats. 
$-19-$

Table IV. A comparison of the species identified in otter scats from Thompson area with those from Gary's Lake.

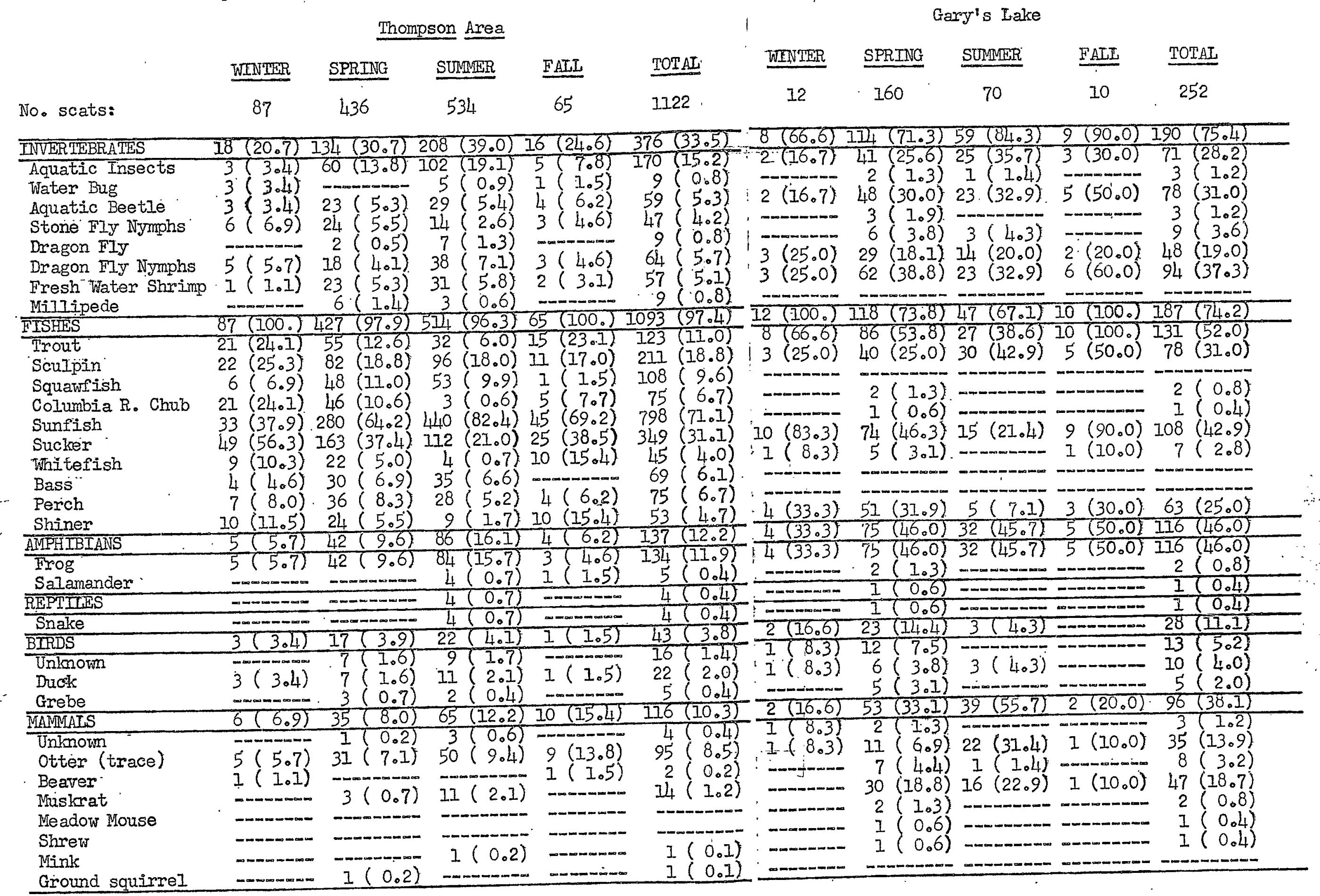


At Gary's, the fish occurring in the highest percentage of the scats was the trout $131(52.0 \%)$. Trout appeared mostly in winter $(66.7 \%)$ and fall $(100 \%)$, least in the sumner $(38.6 \%)$. On Thompson area, trout ranked fourth and maintained the same seasonal trend found at the other study area, i.e., highest in winter (24.1\%) and fall (23.1\%), lowest in summer (6.0\%). The ranking fish at the Thompson area was sunfish 798 (71.1\%) with a high in summer (82.4\%) and low in winter. (37.9\%). This fish was not collected or reported to occur in Gary's Iake. Suckers were second in occurrence for both Thompson 349 (31.1\%) and Gary's 108 (42.9\%)。 They showed the same seasonal trend for the respective areas; high in winter $(56.3$ and $83.3 \%)$ and low for the summer $(21.0$ and $21.4 \%)$. Third place for Gary's was the sculpin, occurring in 78 (3I.0\%) and showing greatest for summer $(42.9 \%)$ and fall $(50.0 \%)$. At Thompson's the third important fish was also the sculpin $211(18.8 \%)$. It showed about equal relations throughout the spring $(18.8 \%)$, summer $(18.0 \%)$ and fall (17.0\%) but increased in winter (25.3\%). The fish occurring fourth at Gary's was the shiner $63(25.0 \%)$. These were present in at least $30 \%$ of the scats for the winter, spring and fall with lowest representation during the summer (7.1\%)。 This low trend for shiner also appears for the same period in the Thompson area $(1.7 \%)$ although its occurrence at no season approached that at Gary's. Squawfish, bass and perch were entirely absent from any anaIyzed scats collected from Gary's area and the only occurrence for a Columbia river chub in 2 scats and sunfish in $I$ were recorded for the spring. Evidence suggests these were picked up elsewhere. For Thompson, 
the squawfish had a total occurrence of $108(9.6 \%)$. It was greatest for spring 48 (1..0\%) and summer 53 (9.9\%); lowest for faII I (1.5\%). CoIumbia river chub totaled $75 .(6.7 \%)$; of these 21 (24.1\%) were in the winter, $46(10.6 \%)$ in spring and $3(0.6 \%)$ in summer. of all appearances of bass $69(6.1 \%)$, spring $30(6.9 \%)$ and summer $35(6.6 \%)$ were most prominent followed by $4(4.6 \%)$ for winter and entirely absent during the fall. Perch were found in $75(6.7 \%)$ scats; seasonal usage ranged from 5.2 to 8.3\%. Total whitefish occurrence was 45 (4.0\%). These appeared mostly in the fall 10 (15.4\%) and winter 9 (10.3\%) followed by spring $22(5.0 \%)$ and then sumer $4(0.7 \%)$. This same trend appeared for Gary's lake but too few data are available for definite conclusions. OnIy 7 (2.8\%) appeared, with faII I (10.0\%) and winter I (8.3\%) highest, followed by spring 5 (3.1\%) and none for summer.

Invertebrates are 2 to 3 times greater in percent occurrence at Gary's than at Thompson area for all seasons but no season had less than 20\% for either area. The most prominent at Gary's were: Fresh water shrimp $94(37.3 \%)$, aquatic beetle 78 (31.0\%), "aquatic insects" 71 (28.2\%) and dragon fly nymph 48 (19.0\%). At Thompson area "aquatic insects" were present in 170 ( $15.2 \%)$ of the total; all others were represented less than $6 \%$ each. Stonefly nymphs (Plecoptera) were represented in all seasons at Thompson but only during the spring at Gary's。

Frogs appeared in $46.0 \%$ of the collection at Gary's and were recorded for $33.3 \%$ or more for all seasons. The Thompson occurrence was $11.9 \%$ showing highest for summer $15.7 \%$ and Iowest in fall 4.6\%. Salamanders 
were taken as a trace in both areas.

Hair and mammal remains were in 96 (38.1\%) scats at Gary's and 116 (10.3\%) at Thompson. Excluding traces of otter hair the figures are 62 $(24.6 \%)$ and $22(2.0 \%)$. Nuskrat was the most numerous in scats containing hair found in both areas. Of the total 47 (18.7\%) containing muskrat hair at Gary's, 30 (18.8\%) were in the spring, 16 (22.9\%) in summer, I (10.0\%) In fall and absent for winter. The Thompson area scats with muskrat hair I4 (1.2\%), was highest for summer II (2.1\%) followed by spring 3 (0.7\%) and absent in both winter and fall.

Beaver occurrence was $8(3.2 \%)$ for Gary's and only $2(0.2 \%)$ for the Thompson area. AII usage at Gary's was in spring 7 (4.4\%) except I (1.4\%) in summer. At Thompson it was recorded in 1 scat each for winter and fall. Usage of other mammals for both areas was too insignificant for comparison (Table 2).

Of the 28 (11.1\%) scats from Gary's having feathers, 23 (14.4\%) occurred in the spring, $3(4.3 \%)$ in sumer and $2(16.6 \%)$ in winter. Thirm teen $(5.2 \%)$ were of unknom identity, $10(4.0 \%)$ were duck and $5(2.0 \%)$ grebes. AIl grebes were recorded for the spring period. Duck appeared in $6(3.8 \%)$ spring scats, $3(4.3 \%)$ in summer, $1(8.3 \%)$ in winter and none in fall. Spring $17(3.9 \%)$ and sumer $22(4.1 \%)$ shared about equal importance for feather occurrence recorded for Thompson area. From this area 16 (1.4\%) were classified as unlnown for the total $43(3.8 \%)$. Thenty-two $(2.0 \%)$ were duck and $5(0.4 \%)$ grebes. Ducks appeared in in $(2.1 \%)$ scats during the summer, $7(1.6 \%)$ in spring, $3(3.4 \%)$ in winter 
and $I(1.5 \%)$ in fall. Grebes were recorded for spring $3(0.7 \%)$ and summer $2(0.4 \%)$. The incidence of feather occurrence was greatest during June at Gary's, whereas it was highest during August at Thompson area. Reptiles appeared in $4(0.7 \%)$ scats, all from sumner collections at Thompson and $1(0.6 \%)$ for the spring at Gary's.

\section{Tapeworm Incidence}

Tapeworm proglottids occurred in scats from both areas. They were in $12(8.6 \%)$ of the April scats with 11 (16.2\%) for Thompson and 1 (1.4\%) for Gary's: 17 (9.7\%) for Mays 17 (11.6\%) and zerog 17 (6.1\%) for June, $I 6(7.2 \%)$ and $I(1.7 \%) ; I_{4}(5.7 \%)$ for JuIy, II (5.I\%) and $3(9.1 \%) ; 20$ (7.2\%) for August, $20(7.8 \%)$ and zero. Scats contained from 2 to 76 proglottids which ranged from $1 / 8$ to $1 \frac{1}{2}$ inches. A collection of 20 squawfish from the Pleasant Valley Fisher river, adjacent to an often used otter latrine, revealed 8 to contain Iarval tapeworms in their body cavity. These were found to a lesser extent in shiner and perch. The proglottids and larval stages were both identified as Ligula intestinalis by the Agricultural Research Center, BeItsville, Maryland. Wardle (1935) mentions this tapeworm as frequent in fish eating birds.

\section{DISCUSSION}

The data indicate that the food of the otter varies within restricted limits from one area to another. The reasons for these differences are not readily interpreted. In some cases it seems to be a case of availability of prey (numbers) but in others this is not readily apparent. It 
seems obvious that the habits of certain fishes would make them more vulnerable than others irrespective of total populations. It follows that the Iimited sampling of fish populations by gill netting, electric shocking, and fishing did not necessarily indicate the relative abundance of vulnerable populations. The predominent fish, sunfish (71.I\% of scats from Thompson), eaten by the otter was not taken in any great numbers by sampling. It was noted while walking the Iake shores that sunfish were abundant close to the water's edge during the spring and summer seasons. Selective angling in a few of these places did increase the sunfish catch but still not in proportion to their occurrence in scats. In all probability the habits of the sunfish, during at least some periods, make them more available to the otter. One observation of two otter in a small lake showed their manner of "hunting" to be that of circling the lake rather close to the shore line. On the other hand, the high incidence of sunfish in the scats at Thompson could possibly indicate a preference for this species but at Gary's where sunfish were absent otter were equally abundant and diverted their attention towards other prey.

The populations of bass, trout and shiner as indicated by sampling were also lower than is suggested by their occurrence in scats.

In contrast to the fishes above, the squawfish and Columia river chub did not occur as frequently in scats as. their apparent abundance indicated by fishing in pools adjacent to often used latrines would suggest. One catch for 30 minutes of fishing yielded 20 squawfish. At a lake near otter latrines, 3 hours of fishing resulted in a catch of over 
100 squawfish. These fishes were only represented in 16.3\% of the total scats.

Whitefish were taken in deep water gill net sets and in greater proportion than their incidence in droppings. Scheffer (1953) reported the capture of otter (Iutra canadensis) in crab pots set in 60 feet of water. Numbers of perch caught by fishing and gill nets gave an indication of greater occurrence than scat analysis. From 52 scats collected on the lower Thompson Lake, 21 had perch reimains $(40.4 \%)$ and $16(30.8 \%)$ had sunfish. In the upper Thompson Lake, perch were in 21 of 226 scats (9.3\%) and sunfish in 205 scats $(90.7 \%)$. The reasons for the increase of perch in the diet from one end of these lakes to the other is difficult to evaluate.

In some instances there does appear to be a direct correlation between relative abundance and utilization. The catch of sculpins by shocking seemed proportionate to the occurrence in scats as did the numbers of suckers caught in gill nets (Table I).

Otter predation on fur bearers seemed to be in relation to availability. Gary's Lake had a higher incidence of beaver and muskrat than Thompson (Table II) and the degree of utilization was higher. Muskrat remains first appeared in the scats deposited during April for both areas. At Gary's, scats with muskrat reached a peak in June, occurring in 14 . Evidence of muskrat was highest during August at Thompson area, appearing in 5 scats. The predominant occurrence of mskrat remains in the spring and summer suggest the vulnerability of this species when their numbers 
exceed the security levels under prevailing conditions (Errington, 1943. and 1946).

Of the 8 scats containing beaver at Gary's, 5 occurred during April, 2 in May and I for August. The two for Thompson's consisted of one each for fall and winter.

\section{CONCLUSIONS AND RECOMMENDATIONS}

The waters of the Thompson lake region are heavily populated with fishes not particularly sought by fishermen. These fishes constitute a high percent of the diet of the otter. Fishing pressure is light. It is the opinion of the writer that the facts do not justify the conclusion that otter constitute a menace to the sport fishing of the area although they may do some damage Iocally.

The data indicate that otter take some muskrat and beaver particularIy in areas of high populations but a modern interpretation of predatorprey relationships suggests this cannot be interpreted as a true population depressant. It is more suggestive of top heavy vulnerable populations resulting perhaps from insufficient harvests. It would appear that muskrat and beaver trapping in the area should be increased.

The numbers of otter do not appear sufficient to warrant an open season. There is the possibility however, that a limited open season might stimulate an increase in reproduction and survival in this population and create a self imposed protection by residents on an animal now subject to acts of vandali.sm.

The need for a live trapping and marking study to determine home 
range seems apparent to aid in a better understanding and management of this animal. Such information would provide data for management units, population estimates, etc.

Feeding experiments with captives would reveal the value, one way or the other, of using droppings as an indicator of the number of animals in an area. These experiments could also serve as a foundation for determining the relationship between undigested remains found in scats and the number and kinds of animals eaten thus providing a basis for more accurate evaluations of scat analysis.

\section{SUMMARY}

1. A food habits study by scat analysis was conducted in the Thompson Iakes region of Iincoln County, Montana, to help evaluate the economic status of the otter.

2. Otter latrines were located by walking the shore lines of lakes and streams; 96. were discovered on fallen trees, beaver houses and the shore.

3. Otter scats were easily distinguished by size, shape, and odor. A. total of 2209 were collected between April, I952, and May, 1953. Approximate date of deposit was determined for 1374 which were assigned to winter, spring, summer and fall. These constituted the basis for this study.

4. The limited use of electric shocking, gill net sets and fishing were employed in an attempt to obtain the relative abundance of fishes in the various waters. An indication of fur bearer abundance was afforded 
by "sign".

5. Scats were analyzed in a dry state. Each was broken apart in a culture dish with dissecting needle and tweezer. The complete scat was searched for identifiable remains of items in the diet. These were identified by comparisons with reference collections: Hair identifications were restricted to fur bearers (otter, beaver, muskrat, mink); feathers to Anatidae and grebes. All scats and reference collections are at Montana State College.

6. Data are expressed as percent occurrence by seasons which was calculated by dividing the number of scats for a season into the number of occurrences of an item.

7. Data for two separated areas (Thompson and Gary) are compared.

8. For the entire year and for both areas fish remains were identified most frequently, appearing in 1280 (93.2\%) of the scats. Invertebrates were recorded for 566 (41.2\%), amphibians 253 (18.4\%), mammals $212(15.4 \%)$, birds $71(5.2 \%)$ and reptiles $5(0.4 \%)$.

9. Considering all scats, sunfish occurred in 58.2\%, sucker $33.3 \%$, sculpin 21.0\%, and trout 18.5\%. This same order of importance was established for the Thompson area. Gary's lake was: trout 52.0\%, sucker $42.9 \%$, sculpin $31.0 \%$ and shiner $25.0 \%$

10. Dragon fly nymph, aquatic beetles and fresh water shrimp appeared in scats consistently but seldom made up an appreciable percent of the scat. It.was most common to find I-5 of these in a dropping.

11. Frogs were found to be a prominent part of the diet and. were 
found throughout aII seasons.

12. Muskrat occurred in $404 \%$ of total scats but was present in $18.7 \%$ of the collection at Gary's lake and predominant during spring and sumer. The highest incidence was in June, occurring in 14 scats. Beaver appeared in 10 or $0.7 \%$ of all scats with 8 occurring at Gary's and 2 for the Thompson.

13. The data suggest availability to be important in determining the food habits of the otter.

14. Tapeworm proglottids, Iigula intestinalis, were found in scats from both areas.

\section{ITMERATURE CITED}

Crabb, W. D. 194I. Food habits of the prairie spotted skunk in southeastern Iowa. Jour. Mamm., 22:349-364.

Errington, P. I. 1943. An analysis of mink predation upon muskrats in northcentral U. S. Iowa Agric. Exp. Sta., Res. Bull. No. 320:797-9,24. 1946. Predation and vertebrate populations. Quart. Rev. Biol., 21:144-177, 221-245。

Ferrel, C. M., H. R. Leach and D. F. Tillotson. 1953. Food habits of the coyote in California. Galif. Fish and Gane., 39:301-341.

Fisher, E. M. 1940. Early life of a sea otter pup. Jour. Mammo, 21:

\section{$132-137$ 。}

Lagler, K. F. and B. T. Ostenson. 1942. Early spring food of the otter in Michigan. Jour. Wildlife Mgt。, 6:244-254.

Liers, E. E. 1951. Notes on the river otter (Iutra canadensis). Jour. 
Mammo, $32: 1-9$.

Mathiak, H. A. 1938. A key to hairs of the mammals of southern Michigan. Jour. Wildlife Mgt., 2:25l-268。

Mayer, W. V. 1952. The hair of California mammals with keys to the dorsal guard hairs of California mammals. Amer. Mid. Nat., 48:480-512.

Murie, 0. Jo 1940. Notes on the sea otter. Jour. Marmo, 21:119-13I.

Scheffer, $\nabla_{0}$ B. 1953. Otters diving to a depth of sixty feet. Jour.

Mamm., 34:255.

Scott, T.G. 1941. Methods and computation in fecal analysis with reference to the red fox. Iowa State Coll. Joux. Sci., 15:279-285.

Wardle, R. A. 1935. Fish-tapeworm. The Biol. Bd. Canada, BuII. 45. 


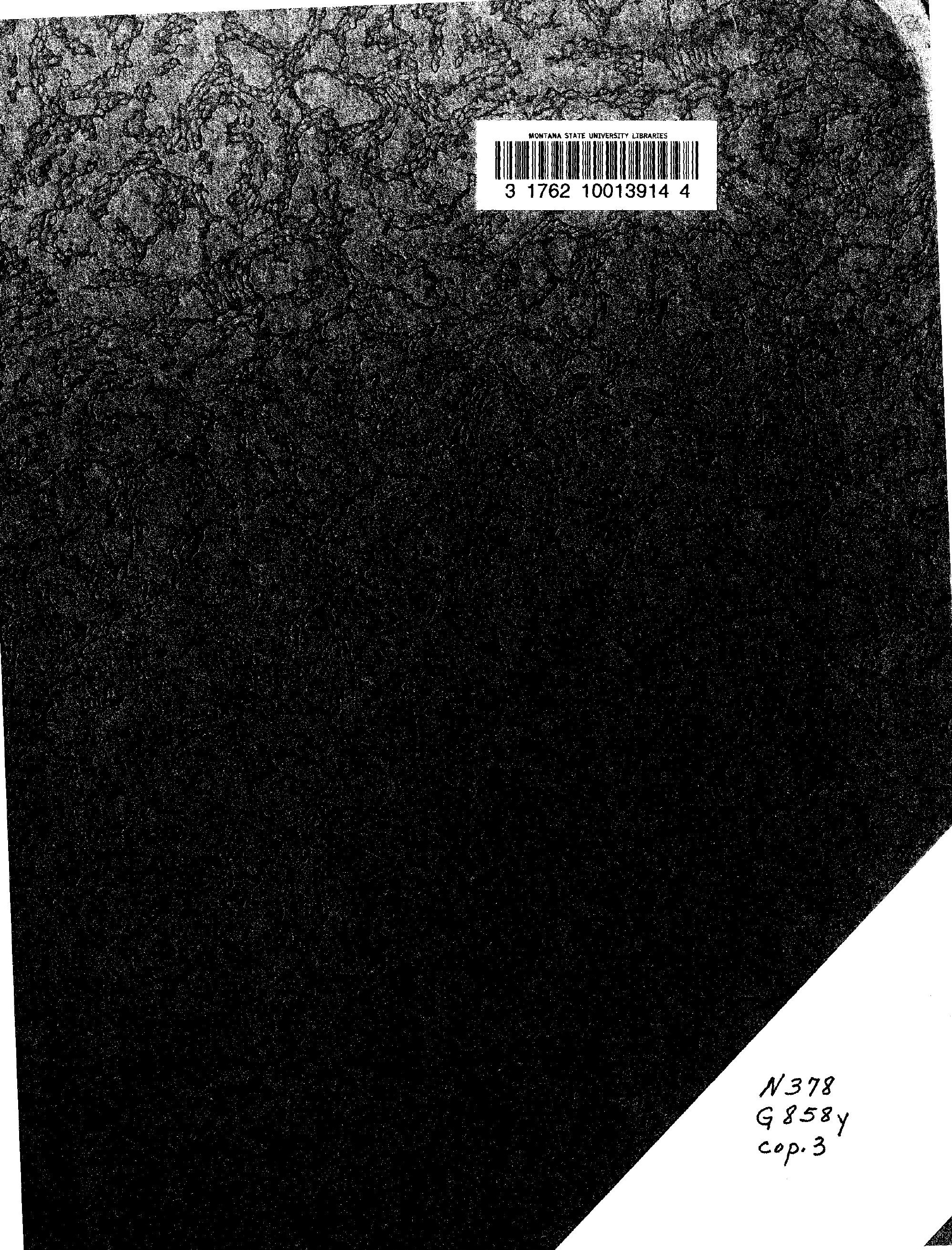

